\title{
Risk Factors Associated with Colostrum Quality in Norwegian Dairy Cows
}

\author{
S. M. Gulliksen, ${ }^{*} \dagger^{1}$ K. I. Lie, †‡ L. Sølverød, $† \S$ and O. Østerås ${ }^{*}$ \\ ${ }^{*}$ Department of Production Animal Clinical Sciences, Norwegian School of Veterinary Science, Oslo, Norway \\ †Department of Cattle Health Services, TINE Norwegian Dairies, Ås, Norway \\ $\ddagger$ Department of Basic Sciences and Aquatic Medicine, Norwegian School of Veterinary Science, Oslo, Norway \\ $\S$ TINE Norwegian Dairies Mastitis Laboratory, Molde, Norway
}

\begin{abstract}
The objectives of the present study were to evaluate colostrum quality in Norwegian dairy cows based on IgG content, and to identify associations between possible risk factors and low colostral IgG. A longitudinal cross-sectional survey on calf health in Norway was performed between June 2004 and December 2006. The participating dairy herds were randomly selected among herds registered in the Norwegian Dairy Herd Recording System as having at least 15 cow years. The participating farmers were requested to sample $10 \mathrm{~mL}$ of colostrum from the first milking after calving from 12 cows that had calved during the defined project period of $365 \mathrm{~d}$. Colostrum samples from 1,250 cows from 119 herds were collected. The material consisted of $451,337,213$, and 249 samples collected from cows in their first, second, third, and fourth parity or more, respectively. Analysis was performed on IgG content by using single radial immunodiffusion. Mixed models with herd as a cluster were fit by using grams of IgG per liter of colostrum as the dependent variable for the statistical analyses. The IgG content in the colostrum sampled ranged from 4 to $235 \mathrm{~g} / \mathrm{L}$, with a median of $45.0 \mathrm{~g}$ of IgG/L, with the 10th, 25th, 75th, and 90th percentiles being 23.1, 31.4, 63.6, and $91.6 \mathrm{~g}$ of IgG/ $\mathrm{L}$, respectively. Altogether, $57.8 \%$ of the samples contained less than the desired $50 \mathrm{~g}$ of IgG/L of colostrum. Cows in their fourth parity or more were found to have significantly higher levels of IgG per liter of colostrum than cows in their first or second parity. Colostrum from cows in their second parity had the lowest level of IgG. Cows calving during the winter months (December, January, and February) produced colostrum with a significantly lower IgG content compared with cows calving in any other season of the year. Somatic cell count, measured after calving, was significantly
\end{abstract}

Received June 15, 2007.

Accepted October 2, 2007.

${ }^{1}$ Corresponding author: stine.gulliksen@veths.no higher in cows producing colostrum of inferior quality compared with those producing high-quality colostrum. Of the total variation in colostrum quality, $13.7 \%$ could be explained by cluster effects within herd. The variation in IgG content in colostrum produced by Norwegian dairy cows indicates a need for improved colostrum quality control and subsequent adjustment of the colostrum feeding regimen to ensure a protective immunological status for newborn calves. Key words: colostrum, dairy cow, calf, somatic cell count

\section{INTRODUCTION}

Colostrum is the secretion from the mammary gland during the first $24 \mathrm{~h}$ after calving (Jaster, 2005) and is an important source of nutritional, growth, and antimicrobial factors for a newborn calf (Blum and Hammon, 2000). It is well documented that colostrum of good quality (i.e., containing high levels of Ig) fed as soon as possible after birth is a necessity to decrease disease susceptibility and neonatal mortality (Wittum and Perino, 1995; Donovan et al., 1998; Tyler et al., 1999a), because newborn calves are agammaglobulinemic at birth (Straub and Matthaeus, 1978). Colostrum contains 3 types of Ig, IgG, IgM, and IgA, where IgG accounts for more than $75 \%$ of the total (Korhonen et al., 2000). Immunoglobulin $\mathrm{G}$ is divided between 2 subclasses, IgG1 and IgG2. The main IgG of colostrum is IgG1. To be classified as colostrum of satisfactory quality, international recommendations set a minimum concentration of $50 \mathrm{~g}$ of IgG/L, based on studies showing significantly higher rates of low serum Ig concentrations in calves receiving colostrum with an IgG content below this limit (Gay et al., 1983; Besser et al., 1991).

Colostrum quality varies distinctly among individual cows (Pritchett et al., 1991; Maunsell et al., 1999; Liberg, 2000) and among different breeds (Muller and Ellinger, 1981; Tyler et al., 1999b). Colostrum containing less than $20 \mathrm{~g}$ of IgG/L to more than $110 \mathrm{~g} /$ 
L has been reported from cows from one single herd (Pritchett et al., 1991). Liberg (2000) found a variation in colostral IgG levels of 4 to $174 \mathrm{~g} / \mathrm{L}$ in a study of colostrum from 660 Swedish dairy cows. Twenty-five percent of the cows had colostrum containing $<50 \mathrm{~g}$ of IgG/L. Shearer et al. (1992) found that only $6.7 \%$ of 2,045 colostrum samples tested had IgG concentrations of $50 \mathrm{~g} / \mathrm{L}$ or more.

Muller and Ellinger (1981) concluded that parity is an important factor in relation to colostral Ig content, with first-calf heifers having a considerably lower colostral IgG content than cows in their third or later parities. Several researchers have found this tendency of increasing colostral Ig concentration with increasing parity of the dam (Devery-Pocius and Larson, 1983; Shearer et al., 1992; Moore et al., 2005). In addition to parity, Pritchett et al. (1991) found the weight of first-milking colostrum to be the most important discriminator between colostrum of low $(<50 \mathrm{~g} / \mathrm{L})$ and high ( $\geq 50 \mathrm{~g} / \mathrm{L})$ IgG1 concentrations. Other factors, such as season of calving, BCS from dry-off to calving (Shearer et al., 1992), IMI during the periparturient period (Oliver and Sordillo, 1988), abortions (Straub and Matthaeus, 1978), and the health status of the cow, (Dardillat et al., 1978) have also been found to influence colostrum quality.

Although colostral IgG concentration is considered one of the most critical factors for sufficient Ig ingestion in newborn calves (Morin et al., 1997), numerous studies have concentrated exclusively on environmental and management factors as reasons for low serum Ig concentrations in calves (Filteau et al., 2003; Simensen et al., 2005). Most research projects on the topic of colostrum quality have focused on Holstein cattle, and only a few studies have examined other dairy breeds (Muller and Ellinger, 1981; Shearer et al., 1992; Quigley et al., 1994). The objectives of the present study were to evaluate the colostrum quality in Norwegian Red Cattle based on IgG content, and to identify associations between possible risk factors and low levels of colostrum IgG content.

\section{MATERIALS AND METHODS}

\section{Selection Procedure}

In February 2004, a longitudinal cross-sectional survey on calf health in Norway was initiated. Herds recorded in the Norwegian Dairy Herd Recording System (NDHRS) as having at least 15 cow years were included for further random sampling (number of cow years $=$ number of days from first calving to culling within 1 yr, divided by 365). A multistage sampling procedure was used to select the study herds. Choosing fairly large herds, according to Norwegian conditions,

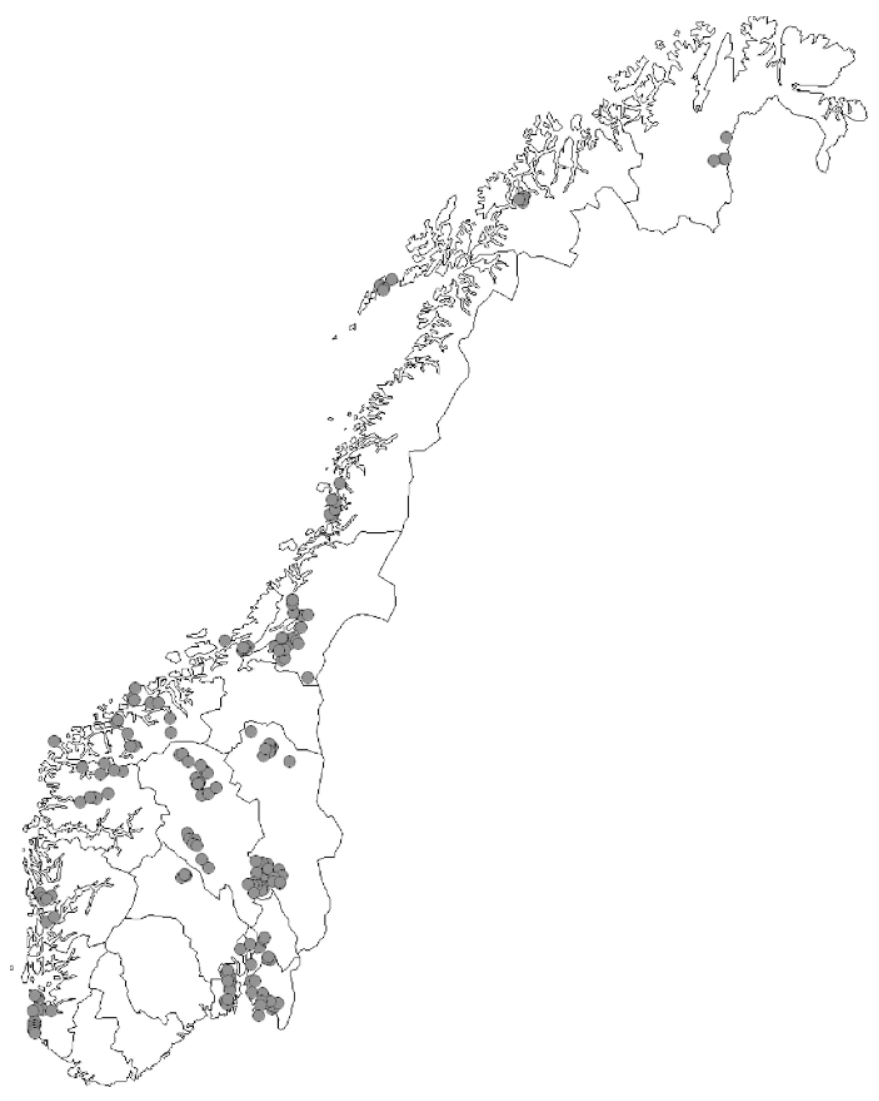

Figure 1. Map of Norway indicating the geographic location of 171 selected dairy herds for participation in a cross-sectional survey on calf health in Norway, conducted between June 2004 and December 2006 .

for the study population was done with regard to the future herd sizes in Norway. Selection of different districts in Norway was based on geographic location, animal density, and that one or more veterinarians in the area had a health service agreement with the Norwegian Cattle Health Services. To cover all parts of Norway, a total of 30 districts were selected. Herds located in the selected districts were stratified based on herd size in the following 4 groups: 1) herds with 15 to 24.9 cow years $(\mathrm{n}=1,807) ; 2$ ) herds with 25 to 49.9 cow years $(\mathrm{n}=568) ; 3$ ) herds with 50 to $99.9 \mathrm{cow}$ years $(\mathrm{n}=62)$; and 4$)$ herds with more than $100 \mathrm{cow}$ years $(n=6)$. By using random computer sampling, 2 herds were selected from each district in the first group, 4 herds were selected from each district in the second group, 2 herds from each district in the third group, and all herds in the last group. All together, 254 dairy herds from all parts of Norway were selected (Figure 1). All selected farmers were invited to join the project through a written invitation. The farmers were then contacted per telephone by the herd's veterinarian or by project personnel to confirm whether they 
were willing to participate. All participating farmers then signed a written contract with the project. A total of 171 farmers were willing to participate in the project, each participating for one full year (365 d). Of the 83 farmers who were unwilling to participate, 42 gave no reason for not participating, 29 thought it involved too much work, 6 were planning on rebuilding or stopping dairy production in the near future, 3 had an insufficient number of calves, and 3 did not want to participate because of personal matters. The overall study period lasted from June 2004 through December 2006 .

\section{Colostrum Sampling}

All participating farmers were asked to submit 10 $\mathrm{mL}$ of colostrum from the first milking after calving from 12 cows that had calved during their defined project period of $365 \mathrm{~d}$. The samples were taken from a healthy quarter. In addition to all equipment necessary for sampling and submitting the samples, the farmers received written instructions detailing how the colostrum sampling should be performed. They were instructed to freeze the colostrum immediately after collection and then submit the samples to The Mastitis Laboratory in Molde, Norway, as soon as colostrum samples from all 12 cows had been obtained. The individual ID number of each cow, the calving date, and the time until first feeding of colostrum were to be registered for each colostrum sample. A total of 1,282 colostrum samples from 119 dairy herds were collected during the study period. The following samples were excluded: samples that were analyzed more than $24 \mathrm{~h}$ after arrival at the laboratory $(\mathrm{n}=22)$, samples from cows already registered with one sample $(\mathrm{n}=4)$, and samples from cows of a breed other than the NRF Norwegian Red cattle breed (NRF; $n=6$ ).

\section{Study Population}

The final study population consisted of colostrum samples from 1,250 cows from 119 herds. The herd size ranged from 15 to 134.8 cow years, with a mean of $34(\mathrm{SD}=29.4)$. A total of $73(61.4 \%)$ herds submitted 12 samples or more, $43(36.1 \%)$ herds submitted between 5 and 12 samples, and $3(2.5 \%)$ herds submitted only one sample each. A total of $1,219(97.5 \%)$ cows were of the NRF breed and $31(2.5 \%)$ were crossbred $\mathrm{NRF}$ and another breed. In total, 451 (36.1\%) of the cows included were first-parity cows, $337(27.0 \%)$ were second-parity cows, 213 (17.0\%) were third-parity cows, and 249 (19.9\%) were cows of fourth parity or more. The seasonal breakdown was as follows: 346 (27.7\%) colostrum samples were from calvings during winter (December to February), 280 (22.4\%) were collected during spring months (March to May), 180 (14.4\%) were from summer calvings (June to August), and $444(35.5 \%)$ were from calvings during autumn (September to November).

\section{Laboratory Analysis}

The colostrum samples were thawed at room temperature and none of the samples were frozen more than once. Analysis on the IgG content in the colostrum was performed using single radial immunodiffusion (Immunocheck, SRID Kit, VMRD Inc., Pullman, WA). All samples were analyzed within $24 \mathrm{~h}$ after arrival at the laboratory. Samples with IgG content exceeding the maximum limits of the SRID test, resulting in ring diameters outside the range of the standard reference curve, were retested after dilution according to the test recommendations.

\section{Health Registrations}

Members of the NDHRS are obligated to report information regularly on diseases and any preventive treatments for each individual animal to a central database managed by TINE Norwegian Dairies. All health registrations are recorded according to a 3-digit coding system used in the Norwegian Cattle Health Recording System, given by the Norwegian Cattle Health Services. In the current study, the following health recordings were extracted from this system: any occurrence of dystocia (calvings where assistance is necessary), mastitis, retained placenta, or milk fever, from $15 \mathrm{~d}$ prior to and $2 \mathrm{~d}$ post calving, as well as a prolonged gestation period ( $>296 \mathrm{~d}$ of gestation, followed by induced calving). Further details regarding the health recording system are given by Østerås et al. (2007). Data on routine milk analysis, including SCC, milk yield, and the amount of concentrates (in $\mathrm{kg}$ ) given to each animal on the test day, were extracted from the NDHRS.

\section{Statistical Analysis}

Data recorded were stored in Microsoft SQL Server and Microsoft Excel (Microsoft Corporation, Redmond, WA) and transferred to SAS, version 9.1 (SAS Institute Inc., Cary, NC) for descriptive statistics and statistical analyses. All 1,250 samples were included for the descriptive statistics. The following cows were excluded from the statistical analysis on milk characteristics: cows with no registrations on concentrate feeding $(\mathrm{n}=$ 20 ) or milk yield after calving $(\mathrm{n}=51)$, cows without registrations regarding the first $\mathrm{SCC}$ after calving $(\mathrm{n}=$ 
65 ), or cows having registrations of the first SCC after calving from a sample collected before $7 \mathrm{~d}$ after calving $(\mathrm{n}=45)$ or later than $66 \mathrm{~d}$ after calving $(\mathrm{n}=53)$. The final data set for further statistical analyses consisted of 1,017 cows from 119 herds.

The normality of colostral IgG in grams per liter was checked visually by using a PROC UNIVARIATE plot. The normality of the untransformed result ( $\mathrm{g}$ of $\mathrm{IgG} / \mathrm{L}$ ) and the log transformation of the result seemed equally acceptable, although the first was slightly right skewed and the other slightly left skewed. Two separate mixed models were fit by using PROC MIXED. In model 1, the untransformed result ( $\mathrm{g}$ of IgG/L of colostrum) was used as the dependent variable and in model 2 , the result as an ordinal variable was used, divided into 8 groups: $<20,21$ to 30,31 to 40,41 to 50,51 to 60,61 to 70 , and 71 to $80 \mathrm{~g}$ of IgG/ $\mathrm{L}$; all samples with an IgG content exceeding $80 \mathrm{~g} / \mathrm{L}$ were included in the eighth group. In both models, herd as well as the sire of the dam were used as random effects. The initial full models included the following fixed effects: herd size, parity, month of calving, kilograms of concentrate fed on the test day, SCC after calving, geometric mean of the last 3 measures of SCC before calving, first recorded milk yield after calving, any occurrence of dystocia, mastitis, retained placenta, or milk fever from $15 \mathrm{~d}$ prior to and $2 \mathrm{~d}$ after calving, and prolonged gestation period, year of sampling, and number of samples per herd. A third multivariable model was fit with colostral IgG content $<30$ or $\geq 30 \mathrm{~g} / \mathrm{L}(0,1)$ as the dependent variable by using PROC GENMOD with a binomial distribution and logit link function with Wald statistics type 3 contrasts. In this model, hierarchical dummy variables were created from SCC, in cells per milliliter, after calving: SCC >10,000, >20,000, >50,000, >100,000, $>200,000$, and $>400,000$. All other fixed effects used in the first 2 models were also included in the third. Nonsignificant variables were removed one by one by using backward stepwise elimination, with inclusion criteria of $P<0.05$. Possible interactions between significant fixed variables were tested. The model fit was evaluated by using -2 log likelihood (Dohoo et al., 2003).

\section{RESULTS}

The colostral IgG content ranged from 4 to $235 \mathrm{~g} / \mathrm{L}$ with a median of $45.0 \mathrm{~g}$ of IgG/L, with the $10 \mathrm{th}$, 25th, 75th, and 90th percentiles being 23.1, 31.4, 63.6, and $91.6 \mathrm{~g}$ of $\mathrm{IgG} / \mathrm{L}$, respectively. The distribution of the IgG content in the colostrum samples is presented in Figure 2. Altogether, $57.8 \%$ of the samples contained less than the desired $50 \mathrm{~g}$ of IgG/L of colostrum.
Parity and SCC after calving were significant factors in models 1 and 2 . The results from model 1 are presented in Table 1. The variation in colostrum IgG content between cows of different parities and cows with different calving seasons is presented in Figures 3 and 4 , respectively. Calving season was found to be significant in both models. The amount of concentrate fed was significant in model 2 and was borderline significant $(P=0.06)$ in model 1 . In the third model, SCC $>50,000$ cell $\mathrm{s} / \mathrm{mL}$ was the only significant factor identified. Cows having SCC $>50,000$ cells $/ \mathrm{mL}$, measured after calving, were more likely to have produced colostrum with an IgG content of $<30 \mathrm{~g} / \mathrm{L}$ than cows with a lower SCC (odds ratio $=1.7 ; 95 \%$ confidence interval: 1.3 to $2.2, P<0.001)$. We found no association between SCC as measured in the previous lactation and subsequent colostral IgG content.

Milk fever, prolonged pregnancy, retained placenta, dystocia, and mastitis were the most frequently registered diseases in participating herds from $15 \mathrm{~d}$ prior to and $2 \mathrm{~d}$ post calving. We found no significant association between these diseases and colostral IgG content.

We found a cluster effect within herd of $13.7 \%$. No cluster effect of the sire of the dam was detected. Colostrum IgG content was not influenced by year of sampling or number of samples per herd.

Time until first feeding of colostrum was recorded for $666(53.0 \%)$ of the 1,250 colostrum samples. Among these, first colostrum was fed within $2 \mathrm{~h}$ after calving in $479(71.9 \%)$ cases, whereas first colostrum was fed within $4 \mathrm{~h}$ after calving in as many as $616(92.6 \%)$ cases.

\section{DISCUSSION}

\section{Descriptive Statistics}

This study shows that the majority of Norwegian dairy cows produce colostrum with an IgG content below $50 \mathrm{~g} / \mathrm{L}$. The average IgG content of $51.7 \mathrm{~g} / \mathrm{L}$ in colostrum from Norwegian dairy cows was lower than the average concentration reported from Jersey cows, which ranged from 65.8 (Quigley et al., 1994) to 66.5 $\mathrm{g}$ of IgG/L (Muller and Ellinger, 1981), and was lower than some reports from Holsteins. Maunsell et al. (1999) reported a mean of $76 \mathrm{~g}$ of IgG/L of colostrum in samples from 101 Holstein cows. On the other hand, our mean of $51.7 \mathrm{~g} / \mathrm{L}$ was somewhat higher compared with that of Pritchett et al. (1991), who reported a mean of $48.2 \mathrm{~g}$ of IgG/L of colostrum in 919 Holstein cows. As in the Swedish study by Liberg (2000), this study gave us an indication of the huge differences among individual cows within the same breed. 


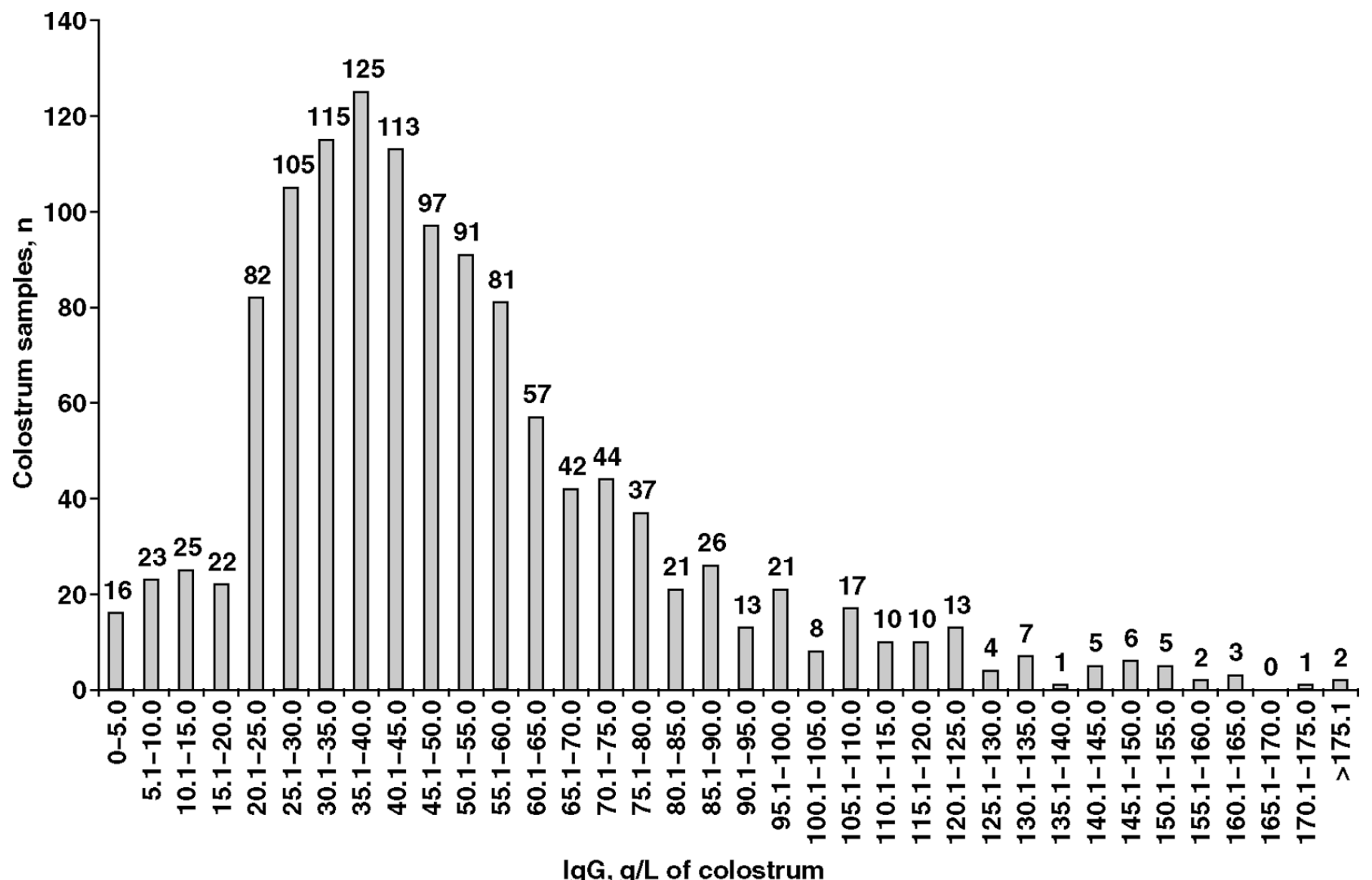

Figure 2. The distribution of IgG content $(\mathrm{g} / \mathrm{L})$ in colostrum samples from 1,250 Norwegian dairy cows, sampled between June 2004 and December 2006.

Table 1. Result estimates of the final mixed model 1 describing effects of parity, month of calving, SCC, and kilograms of concentrate fed on the test day on the IgG content in colostrum samples from 1,017 cows from 119 Norwegian dairy herds, collected between June 2004 and December 2006

\begin{tabular}{|c|c|c|c|c|c|}
\hline Parameter & $\begin{array}{l}\text { Class or } \\
\text { mean (SD) }\end{array}$ & Cows, $\mathrm{n}$ & Estimate & $\mathrm{SE}$ & $P$-value \\
\hline Intercept & - & 1,017 & 63.95 & 6.21 & $<0.001$ \\
\hline \multirow[t]{4}{*}{ Parity } & 1 & 451 & -6.73 & 2.64 & 0.011 \\
\hline & 2 & 337 & -8.90 & 2.64 & $<0.001$ \\
\hline & 3 & 213 & -3.92 & 2.90 & NS \\
\hline & $>3$ & 249 & 0 & - & - \\
\hline \multirow[t]{12}{*}{ Month of calving } & January & 128 & 0 & - & - \\
\hline & February & 103 & 0.06 & 3.99 & NS \\
\hline & March & 116 & 9.30 & 4.16 & 0.025 \\
\hline & April & 98 & 2.75 & 4.25 & NS \\
\hline & May & 66 & 9.20 & 4.90 & 0.061 \\
\hline & June & 77 & 6.85 & 4.74 & NS \\
\hline & July & 47 & 8.37 & 5.53 & NS \\
\hline & August & 56 & 12.22 & 5.34 & 0.022 \\
\hline & September & 134 & 10.49 & 4.21 & 0.011 \\
\hline & October & 158 & 13.30 & 3.80 & $<0.001$ \\
\hline & November & 152 & 3.64 & 3.82 & NS \\
\hline & December & 116 & 3.06 & 3.96 & NS \\
\hline Ln (SCC) & $4.19(1.28)$ & 1,017 & -1.81 & 0.68 & $<0.01$ \\
\hline Concentrate feeding & $8.01(2.47)$ & 1,017 & -0.78 & 0.423 & 0.067 \\
\hline \multirow[t]{2}{*}{ Random effect } & Herd & 119 & 107.19 & & \\
\hline & Random error & & 676.47 & & \\
\hline
\end{tabular}




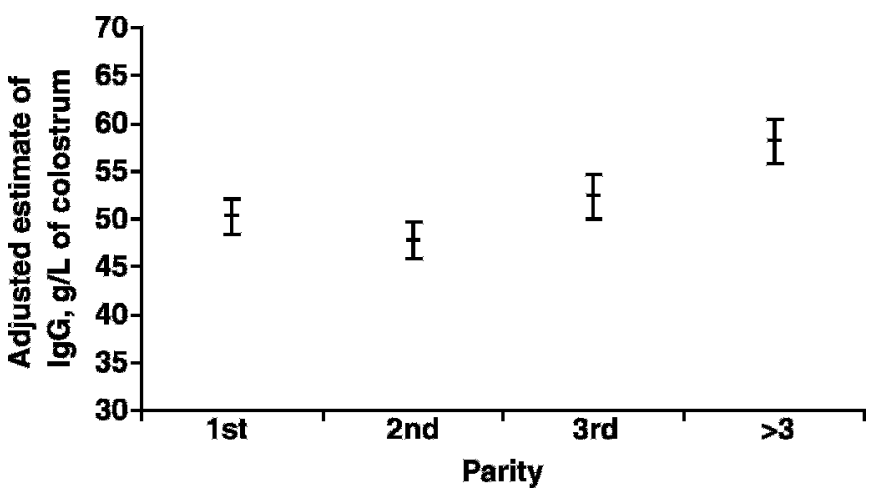

Figure 3. Immunoglobulin G content $(\mathrm{g} / \mathrm{L})$ in colostrum samples from 1,017 cows of different parities (bars: 95\% confidence interval) in 119 Norwegian dairy herds, sampled between June 2004 and December 2006. Estimates are adjusted for all other significant factors.

\section{Statistical Analyses}

The colostral IgG content had a slightly rightskewed distribution, so different models were fit to evaluate possible differences in explanatory variables depending on whether we chose to emphasize high or low IgG values. In model 1, using natural figures, associations with high IgG levels were emphasized. The effect of extreme IgG values was subdued by transforming the result into an ordinal variable in model 2 . The third model was created to focus on factors that could result in the production of colostrum of very poor quality $(<30 \mathrm{~g}$ of IgG/L).

\section{Parity}

The results of this study support the findings of increasing IgG content with increasing parity (Tyler et

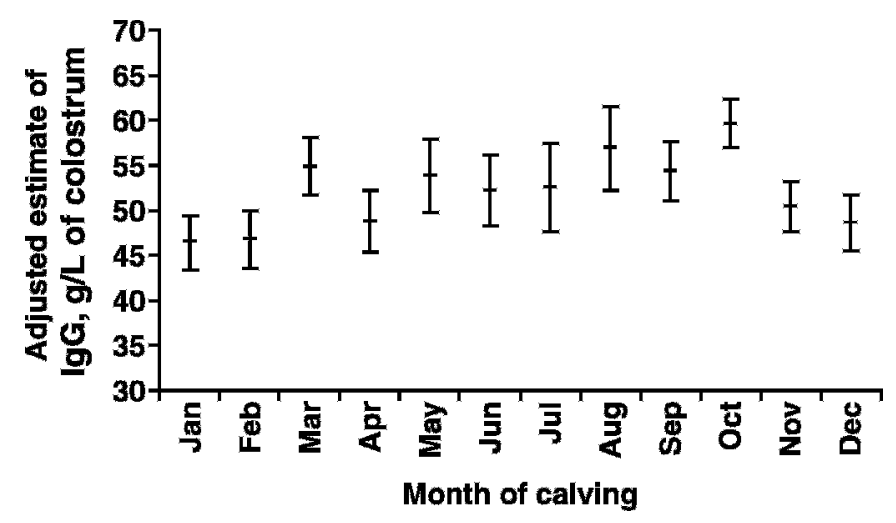

Figure 4. Immunoglobulin $\mathrm{G}$ content $(\mathrm{g} / \mathrm{L})$ in colostrum samples from 1,017 cows with various months of calving (bars: 95\% confidence interval) in 119 Norwegian dairy herds, sampled between June 2004 and December 2006. Estimates are adjusted for all other significant factors. al., 1999b; Moore et al., 2005). This increase was most pronounced between cows of first or second parity and cows of at least four parities. Older cows, being exposed to antigens for a longer time during their life than younger cows, seemed to produce colostrum with higher antibody levels. Even though our results showed a trend of increasing colostrum quality with increasing parity, there is no reason why farmers should discard colostrum from first-parity cows without testing the IgG level. We found that cows in their second parity produced colostrum of poorer quality than both first-parity cows and older cows. This coincides with the results from Quigley et al. (1994) in which colostrum samples from 88 Jersey cows were analyzed. Pritchett et al. (1991) found that secondparity cows had a significantly lower IgG concentrations than older cows, but like Tyler et al. (1999b) and in the present study, they found no significant difference between first- and second-parity cows. An explanation for why colostrum differs between secondparity cows and cows in other parities was not identified.

\section{Calving Season}

In the current study, cows calving during the winter months had significantly lower IgG levels than cows calving in other seasons of the year. In contrast, Pritchett et al. (1991) found that the season of calving did not significantly influence colostral IgG concentration in 900 Holstein cows from a commercial dairy farm. Seasonal variation might be of more importance in Norway than in other countries. The marked variation in climate among the different seasons leads to differences in the occurrence of disease, feeding regimen, and indoor climate, which may influence IgG production. In the current study, cows calving during August, September, and October produced colostrum of higher quality compared with cows calving during other seasons. According to Norwegian law, cows should spend at least $8 \mathrm{wk}$ on pasture each year. The pasture season in Norway is usually between late May and late September, the length depending on the latitude. This entails a change in feeding regimen, often from silage to fresh grass, which might be beneficial when it comes to colostrum quality in cows calving during late summer and autumn. The improvement in colostrum quality in autumn may partly explain the reduced calf mortality rates in Norway during this period of the year (S. M. Gulliksen, unpublished data), although Simensen et al. (2005) found that Norwegian dairy calves born from April through June had the highest serum IgG levels. Gay et al. (1983) discovered that the mean monthly serum IgG1 concentrations in calves 
were lowest in the winter and increased during the spring and summer, to reach a peak in September. The results of the current study indicate that dairy herds with the opportunity to adjust their calving pattern at the herd level should consider seasonal differences in colostrum quality in their decisions.

\section{SCC}

An SCC of $>50,000$ cell $s / \mathrm{mL}$ was the only test-day result found to be significant for the production of colostrum with very low IgG values. Our results are in contrast to those of Maunsell et al. (1999), who found that SCC had no effect on colostral IgG content. On the other hand, we found no association between SCC measured before calving and colostral IgG content; that is, precalving milk characteristics could not predict colostrum quality in our study. Whist and Østerås (2007) showed that the association between SCC and later clinical mastitis begins already at 40,000 to 50,000 cells $/ \mathrm{mL}$, and similar to the results of the current study, established an obvious benefit of low cell counts. Similarly, Kehoe et al. (2007) found that cows from farms with a herd average SCC of $<200,000$ in the month before samples were collected produced colostrum of higher nutrient quality. Lundborg et al. (2003) found an increase in the number of clinical cases of respiratory disease among calves from cows with SCC between 34,500 and 124,000 compared with calves from cows with lower SCC. According to our study, this could be a result of low serum Ig concentrations caused by feeding colostrum of inferior quality.

\section{Cluster Effects}

Numerous studies have restricted the population from which they obtain colostrum samples to one single herd (Pritchett et al., 1991; Shearer et al., 1992); thus, a cluster effect within herds has not been addressed in these studies. According to our results, a cluster effect of $13.7 \%$ implies that management factors that vary among farms (i.e., feeding, environment, housing, etc.) are of importance when it comes to variation in colostrum quality. We found the amount of concentrate fed to be negatively correlated with IgG concentration. The amount of concentrate fed was also highly correlated with milk yield after calving; therefore, the 2 factors could not be included in the statistical models simultaneously. However, testing the model fit with either one of the 2 variables showed that including the amount of concentrate fed gave a slightly better model. The negative correlation between colostrum quality and these 2 variables could be an indication of a negative consequence of intensive feeding or a dilution effect on colostrum IgG, because intensive feeding will result in a higher daily milk yield. We identified no noteworthy cluster effect of sire of the dam, indicating a possibility of no heritability for colostrum quality, in spite of high heritability on milk yield (Dechow and Norman, 2007).

\section{Representativity}

All farms participating in the study had a herd size exceeding 15 cow years, resulting in a mean herd size considerably larger than the average herd size of 17 cow years in Norway today. Cattle production in Norway has undergone many changes the last 10 to 20 $\mathrm{yr}$ and is currently changing rapidly. The authorities demand that all cattle be housed in free stalls by 2024 and the number of cooperatives is increasing, hence the herds are getting larger. Participation in the project was voluntary. This might have led to herdsmen more interested in calf health, who are running wellmanaged farms, being overrepresented in the study. On the other hand, farms already having calf health problems might have been more motivated to participate for that same reason.

The colostrum samples in this study were sampled from one random, but healthy, quarter from each cow. This was done under the assumption of minimal differences among the 4 quarters and to ease the work load of the farmers. The likelihood of differences in IgG content among the 4 quarters in the same udder has been studied, but the studies are few and often small, and the results differ. In a study of 113 Holstein cows, Maunsell et al. (1999) found no difference in IgG content in colostrum from different quarters.

The participating farmers were instructed to sample colostrum from the cow's first milking as soon as possible after calving. For practical reasons, colostrum from cows calving at night might have been collected several hours after calving. This may have lowered the IgG level in these samples. In the current study, the first colostrum fed was reported to be carried out within 4 $\mathrm{h}$ in $92.6 \%$ of the cases where this registration was done. In all likelihood, the colostrum samples were collected before or at the time of first colostrum feeding. There was no difference in the distribution of colostrum IgG content between samples for which the time until feeding was reported and those for which this registration was missing. Therefore, we assume that the vast majority of the samples in this study were collected within $4 \mathrm{~h}$ after calving. Moore et al. (2005) found that colostrum sampled $6 \mathrm{~h}$ after calving or later had a significantly lower IgG content than colostrum collected $2 \mathrm{~h}$ after calving. Pritchett et al. (1991) and Straub and Matthaeus (1978) found that 
as long as the cows were milked within 8 or $9 \mathrm{~h}$ after calving, respectively, the interval between calving and first milking had no significant influence on the colostral IgG1 concentration. The possibility of prior nursing by calves after calvings on pasture or in free stalls without the farmer noticing may have resulted in the sample being colostrum from a later milking, thereby reducing the colostral IgG content in the sample.

\section{Practical Consequences}

A common phenomenon in the majority of the research done on colostrum quality, including the present one, is the wide range of variation in colostral $\mathrm{IgG}$ content from different cows within a restricted area. These individual variances make it difficult to draw conclusions concerning different risk factors and thereby providing sufficient advising when it comes to management and colostrum quality.

Until now, most research has concentrated on aspects of colostral management other than colostrum quality, such as time of feeding, volume fed, and feeding method. Because most dairy calves are fed a fixed volume of colostrum after birth, colostral IgG concentration is an important determinant of adequate passive transfer in calves. Because the majority of the Norwegian dairy cow population seems to produce colostrum of inferior quality compared with international recommendations, this study indicates a need for improved colostrum quality control and subsequent adjustment of the colostrum feeding regimen to ensure a protective immunological status of newborn calves.

\section{ACKNOWLEDGMENTS}

The authors would like to thank all the participating farmers, veterinarians, and laboratory personnel for their involvement in the current research. The study was funded by TINE Norwegian Dairies BA (Oslo, Norway), Norwegian Meat Research Centre (Oslo, Norway), and the Research Council of Norway (Oslo, Norway). Access to production and health data was given by the Norwegian Dairy Herd Recording System (Ås, Norway) and the Norwegian Cattle Health Services (Ås, Norway) in agreement number 2/2004.

\section{REFERENCES}

Besser, T. E., C. C. Gay, and L. Pritchett. 1991. Comparison of three methods of feeding colostrum to dairy calves. J. Am. Vet. Med. Assoc. 198:419-422.

Blum, J. W., and H. Hammon. 2000. Colostrum effects on the gastrointestinal tract, and on nutritional, endocrine and metabolic parameters in neonatal calves. Livest. Prod. Sci. 66:151-159.

Dardillat, J., G. Trillat, and P. Larvor. 1978. Colostrum immunoglobulin concentration in cows: Relationship with their calf mor- tality and with the colostrum quality of their female offspring. Ann. Rech. Vet. 9:375-384.

Dechow, C. D., and H. D. Norman. 2007. Within-herd heritability estimated with daughter-parent regression for yield and somatic cell score. J. Dairy Sci. 90:482-492.

Devery-Pocius, J. E., and B. L. Larson. 1983. Age and previous lactations as factors in the amount of bovine colostral immunoglobulins. J. Dairy Sci. 66:221-226.

Dohoo, I., W. Martin, and H. Stryhn. 2003. Mixed models for discrete data. S. M. McPike, ed. Veterinary Epidemiologic Research. 1st ed. AVC Inc., Charlottetown, Transcontinental Prince Edward Island.

Donovan, G. A., I. R. Dohoo, D. M. Montgomery, and F. L. Bennett. 1998. Associations between passive immunity and morbidity and mortality in dairy heifers in Florida, USA. Prev. Vet. Med. $34: 31-46$

Filteau, V., E. Bouchard, G. Fecteau, L. Dutil, and D. DuTremblay. 2003. Health status and risk factors associated with failure of passive transfer of immunity in newborn beef calves in Quebec. Can. Vet. J. 44:907-913.

Gay, C. C., T. C. McGuire, and S. M. Parish. 1983. Seasonal variation in passive transfer of immunoglobulin G1 to newborn calves. J. Am. Vet. Med. Assoc. 183:566-568.

Jaster, E. H. 2005. Evaluation of quality, quantity, and timing of colostrum feeding on immunoglobulin G1 absorption in Jersey calves. J. Dairy Sci. 88:296-302.

Kehoe, S. I., B. M. Jayarao, and A. J. Heinrichs. 2007. A survey of bovine colostrum composition and colostrum management practices on Pennsylvania dairy farms. J. Dairy Sci. 90:4108-4116.

Korhonen, H., P. Marnila, and H. S. Gill. 2000. Milk immunoglobulins and complement factors. Br. J. Nutr. 84(Suppl. 1):S75-S80.

Liberg, P. 2000. Råmjølksutfodring—En god start förlänger livet [Colostrum feeding-A good start prolongs life]. Pages 133-139 in Proc. Vet. Mt., Uppsala, Sweden. M. Lundvall, ed. Swed. Soc. Vet. Med., Stockholm, Sweden.

Lundborg, G. K., P. A. Oltenacu, D. O. Maizon, E. C. Svensson, and P. G. A. Liberg. 2003. Dam-related effects on heart girth at birth, morbidity and growth rate from birth to 90 days of age in Swedish dairy calves. Prev. Vet. Med. 60:175-190.

Maunsell, F. P., D. E. Morin, P. D. Constable, W. L. Hurley, and G. C. McCoy. 1999. Use of mammary gland and colostral characteristics for prediction of colostral IgG1 concentration and intramammary infection in Holstein cows. J. Am. Vet. Med. Assoc. $214: 1817-1823$

Moore, M., J. W. Tyler, M. Chigerwe, M. E. Dawes, and J. R. Middleton. 2005. Effect of delayed colostrum collection on colostral IgG concentration in dairy cows. J. Am. Vet. Med. Assoc. 226:1375-1377.

Morin, D. E., G. C. McCoy, and W. L. Hurley. 1997. Effects of quality, quantity, and timing of colostrum feeding and addition of a dried colostrum supplement on immunoglobulin G1 absorption in Holstein bull calves. J. Dairy Sci. 80:747-753.

Muller, L., and D. Ellinger. 1981. Colostral immunoglobulin concentrations among breeds of dairy cattle. J. Dairy Sci. 64:17271730.

Oliver, S. P., and L. M. Sordillo. 1988. Udder health in the periparturient period. J. Dairy Sci. 71:2584-2606.

Østerås, O., H. Solbu, A. O. Refsdal, T. Roalkvam, O. Filseth, and A. Minsaas. 2007. Results and evaluation of thirty years of health recordings in the Norwegian dairy cattle population. J. Dairy Sci. 90:4483-4497.

Pritchett, L. C., C. C. Gay, T. E. Besser, and D. D. Hancock. 1991. Management and production factors influencing immunoglobulin G1 concentration in colostrum from Holstein cows. J. Dairy Sci. 74:2336-2341.

Quigley, J. D., III, K. R. Martin, H. H. Dowlen, L. B. Wallis, and K. Lamar. 1994. Immunoglobulin concentration, specific gravity, and nitrogen fractions of colostrum from Jersey cattle. J. Dairy Sci. 77:264-269.

Shearer, J., H. O. Mohammed, J. S. Brenneman, and T. Q. Tran. 1992. Factors associated with concentrations of immunoglobu- 
lins in colostrum at the first milking post-calving. Prev. Vet. Med. 14:143-154.

Simensen, E., K. Nybø, T. Malmo, and O. Østerås. 2005. Lave nivåer av gammaglobuliner hos nyfødte kalver. Norsk Veterinærtidsskrift. 117:533-540.

Straub, O. C., and W. Matthaeus. 1978. The immunoglobulin composition of colostrum and the persistence of acquired immunoglobulins and specific antibodies in the calf. Ann. Rech. Vet. 9:269-275.

Tyler, J. W., D. D. Hancock, J. G. Thorne, C. C. Gay, and J. M. Gay. 1999a. Partitioning the mortality risk associated with inade- quate passive transfer of colostral immunoglobulins in dairy calves. J. Vet. Intern. Med. 13:335-337.

Tyler, J. W., B. J. Steevens, D. E. Hostetler, J. M. Holle, and J. L. Denbigh Jr. 1999b. Colostral immunoglobulin concentrations in Holstein and Guernsey cows. Am. J. Vet. Res. 60:1136-1139.

Whist, A. C., and O. Øster̊s. 2007. Associations between somatic cell counts at calving or prior to drying-off and clinical mastitis in the remaining or subsequent lactation. J. Dairy Res. 74:66-73.

Wittum, T. E., and L. J. Perino. 1995. Passive immune status at postpartum hour 24 and long-term health and performance of calves. Am. J. Vet. Res. 56:1149-1154. 